Грицунь О.М., Рогальський Р.Б., Бура Р.Р.

Національний університет «Львівська політехніка»

\title{
ВИЗНАЧЕННЯ ОПТИМАЛЬНОЇ ТРИВАЛОСТІ СВІТЛОФОРНОГО ЦИКЛУ НА ПЕРЕХРЕСТЯХ 3 ЖОРСТКИМИ ТИПАМИ РЕГУЛЮВАННЯ
}

\begin{abstract}
У роботі проведено аналіз існуючих методів розрахунку тривалості світлофорного циклу регулювання. Наведено порівняння максимальної довжини черги транспортних засобів, кількості зупинених автомобілів на заборонний сигнал світлофора та транспортної затримки за різних режимів регулювання (тривалість циклу розрахована за методикою Ф. Вебстера та за методикою А. Міллера). Встановлено, що найменша затримка спостерігається при тривалості циклу, яка є розрахованою за методикою А. Міллера.

Ключові слова: транспортний потік, світлофорний цикл, імітаційне моделювання, довжина черги, транспортна затримка, інтенсивність руху.
\end{abstract}

Постановка проблеми. Пропуск транспортних та пішохідних потоків набуває все більшого значення в проблемі організації та забезпечення безпеки дорожнього руху, викликаного зі значним зростанням автомобільного парку. Її рішення пов'язане з вимогою зменшити затримки учасників дорожнього руху, підвищити ефективність використання вулично-дорожньої мережі за рахунок чіткої організації пересування транспортних та пішохідних потоків [1,2].

Найкращі умови пропуску транспортних потоків (ТП) на перехресті, з точки зору мінімізації затримок та забезпечення максимальної безпеки руху, створюються шляхом розділення їх в просторі, тобто транспортних розв'язок у різних рівнях [1-4]. Проте, це дорогий спосіб, який пов'язаний, як правило, з перебудови всієї транспортної системи. Більш поширений спосіб - розподіл ТП на перехресті за допомогою світлофорного регулювання (СФР), тобто почергового пропуску транспортних та пішохідних потоків [2,3].

Крім того, застосовуються методи розрахунку режимів СФР, які побудовані на дослідженнях проведених у 90-х роках. Під час розрахунку тривалості світлофорного циклу (СФЦ) регулювання відбувається нераціональне розділення основних тактів, в результаті чого збільшуються затримки транспортних засобів (Т3) і викиди відпрацьованих газів перед стоп-лініями [1-3].

Існуючі методи розрахунку тривалості СФЦ не дають достатньо достовірних розрахунків потенціалів регульованих перехресть, тривалості основних і проміжних тактів при відповідних інтенсивностях ТП та геометричних параметрах вулично-дорожньої мережі та інших умов руху, а також вимогам оптимального управління i забезпечення безпечного пропуску транспортних $\mathrm{i}$ пішохідних потоків на них $[1,3,5]$. Разом 3 цим визначення оптимальної тривалості СФЦ регулювання недостатньо вивчені. Зокрема, не досліджено транспортні затримки за різних методик розрахунку тривалості СФЦ.

Принципи оптимальності в управлінні дорожнім рухом на регульованих перехрестях ще мало вивчені, оскільки нормативи в цій області побудовані на експертних оцінках без використанням програмних середовищ. Імітаційне моделювання дає можливість визначити показники ефективності організації дорожнього руху, порівняння варіантів побудови й алгоритмів функціонування транспортної системи, перевірки стійкості режимів системи при малих вхідних відхиленнях перемінних від розрахункових значень $[3,6]$. Виходячи із сказаного, метою роботи є визначення оптимальної тривалості світлофорного циклу регулювання, їх аналіз на основі імітаційного моделювання руху ТП.

Результати досліджень. У практиці регулювання дорожнього руху для розрахунків параметрів СФЦ застосовуються різні рішення. Однак тривалість циклу СФР при цьому дає відхилення 4 - $12 \%$. Розподіл роздільною сигналів в межах циклу є неоптимальним, а неточність їх розрахунку доходить до $30 \%[2,3]$.

У найпростішому випадку за випадкового прибуття ТЗ до перехрестя мінімальна тривалість циклу може визначатись $[2,3,5,7]$ :

$$
T_{u}=\frac{1,5 \cdot T_{n}+5}{1-\sum_{i=1}^{n} y_{i}},
$$


де $T_{n}$ - сума проміжних тактів, с;

$y_{i}-$ фазовий коефіцієнт в $i$-ій фазі регулювання (максимальне із співвідношень інтенсивності руху Т3 за досліджуваний період до потоку насичення в певному напрямку $i$-ої фази регулювання);

$n$-кількість фаз у циклі регулювання.

Вона запропонована англійським дослідником Ф. Вебстером на основі мінімізації транспортної затримки.

Тривалість основного такту $t_{o_{i}}$ в $i$-й фазі регулювання пропорційна розрахунковому фазовому коефіцієнту цієї фази $[2,3,5,7]$ :

$$
t_{o_{i}}=\frac{\left[\left(T_{u}-T_{n}\right) \cdot y_{i}\right]}{Y},
$$

За високої інтенсивності руху і недостатньої пропускної здатності перехрестя (низькі значення $M_{m i j}$ ) сума розрахункових фазових коефіцієнтів $Y$ прямує до одиниці, а тривалість циклу до безмежності $[1,5]$.

Виходячи з точки зору безпеки руху, тривалість циклу більше 120 с вважається недопустимою, оскільки водії за тривалого очікування дозвільного сигналу можуть прийняти світлофор несправним і почати рух на заборонний сигнал. Якщо розрахункове значення $T_{u}$ перевищує $120 \mathrm{c}$, необхідно понизити значення сумарного фазового коефіцієнта. Із цих же міркувань недоцільно приймати тривалість циклу менше 25 с $[1,5]$.

Іншим англійським фахівцем А. Міллером на базі фазового коефіцієнта розроблено метод визначення тривалості основного таку світлофорного регулювання [7]:

$$
t_{o}=\frac{T_{n}+2 \sqrt{I \cdot T_{n} /\left(M_{u i j} / 3600\right)}}{1-Y},
$$

де $I$ - відношення середнього квадратичного відхилення кількості автомобілів, які прибувають до перехрестя за цикл регулювання $(\sigma)$ до середньої кількості цих автомобілів $\left(\lambda_{c e p}\right)$,

$I=\sigma / \lambda_{\text {cep }}$.

Отже, завдання розрахунку параметрів СФЦ при довільних характеристиках ТП може бути вирішена за допомогою універсального методу оптимізації - імітаційного моделювання. Для проведення імітаційного моделювання не потрібно обчислень ні похідних, ні будь-яких інших характеристик. Даний метод широко застосовується, зокрема на визначення транспортних затримок при різних методах регулювання.

Порівняння методів розрахунку тривалості СФЦ регулювання під час їхнього моделювання дає можливість оцінити транспортні затримки за різної інтенсивності та складу ТП, тривалості дозвільного сигналу світлофора. Як зазначалось раніше, тривалість циклу регулювання залежить від порівняння фактичної інтенсивності руху на підходах до перехрестя і пропускної здатності (потоків насичення) цих підходів. Тому, ці параметри розглядаємо у якості початкових даних для розрахунку оптимальної тривалості СФЦ регулювання.

Для визначення оптимальної тривалості СФЦ обрано чотири перехрестя магістральних вулиць iз жорсткими типами регулювання, а саме перехрестя вулиць Городоцька - Кульпарківська (рис. 1), вулиць Шевченка - Левандівська (рис. 2), вулиць Стрийська - Сахарова (рис. 3), вулиць Липинського - Промислова - Миколайчук (рис. 4). 


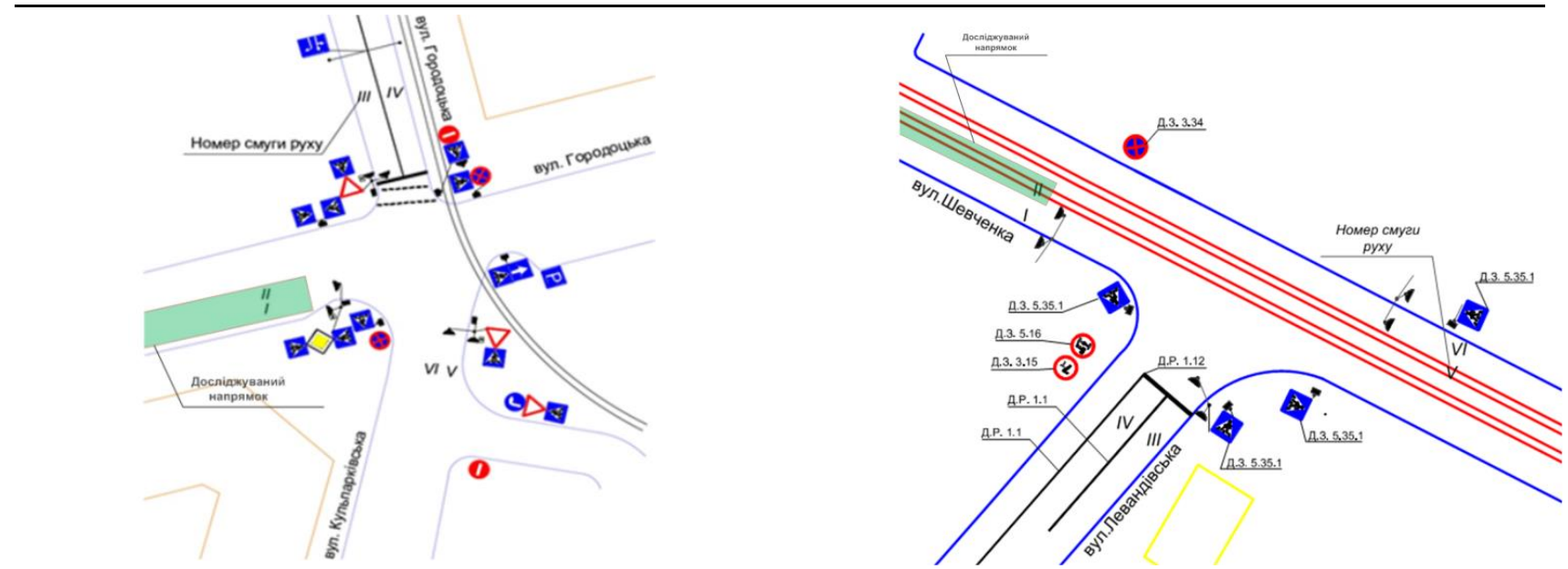

Рисунок 1. Схема організації дорожнього руху на регульованому перехресті вулиць Городоцька - Кульпарківська 3 зображенням смуг руху руху на регульованому перехресті вулиць Шевченка - Левандівська з зображенням смуг руху

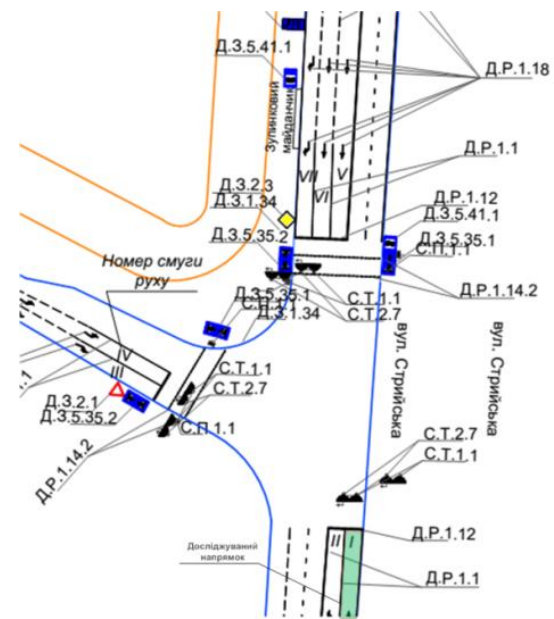

Рисунок 3. Схема організації дорожнього руху на регульованому перехресті вулиць Стрийська - Сахарова 3 зображенням смуг руху

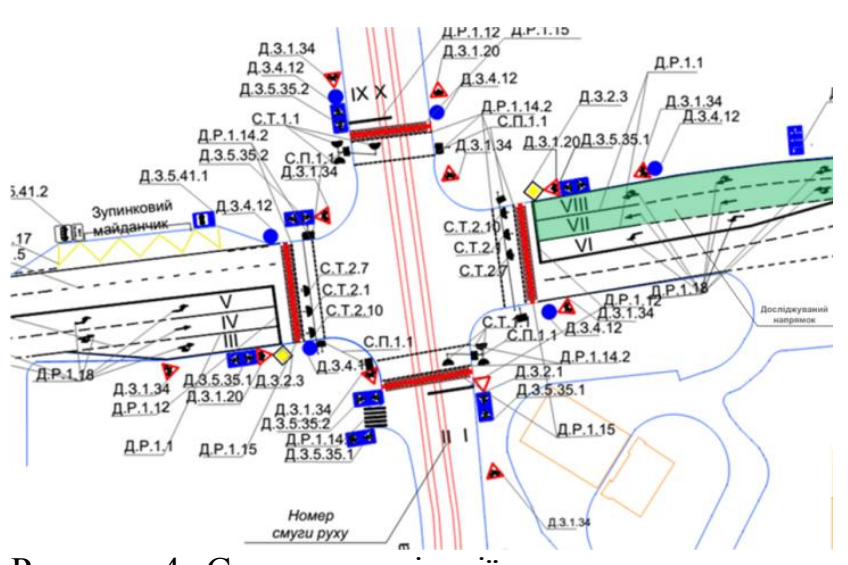

Рисунок 4. Схема організації дорожнього руху на регульованому перехресті вулиць Липинського Промислова - Миколайчука з зображенням смуг руху

Під час досліджень на головному напрямку виміряно інтенсивність та склад ТП, режим СФР, параметри перехрестя, транспортну затримку на регульованих перехрестях за існуючої схеми розташування технічних засобів організації дорожнього руху.

Залежність тривалості циклів світлофорного регулювання від інтенсивності ТП для досліджуваних регульованих перехресть головного напрямку (рис.1 - 4) наведено в табл. 3.5. Розрахунок тривалості СФЦ регулювання побудовано за методикою Ф. Вебстера (формула (1)) та А. Міллера (формула (3)).

3 метою порівняння транспортної затримки та довжини черги за різних режимів регулювання (тривалість циклу розрахована за методикою Ф. Вебстера та за методикою А. Міллера) досліджено: підхід з вулиці Городоцька; підхід з вулиці Шевченка; підхід з вулиці Стрийська; підхід 3 вулиці Липинського. Шляхом імітаційного моделювання інтенсивність змінювалася інтенсивність ТП: для перехрестя вулиць Городоцька - Кульпарківська від 1300 до 1900 од./год.; для перехрестя вулиць Шевченка - Левандівська від 800 до 1400 од./год.; для перехрестя вулиць Стрийська - Сахарова від 800 до 1700 од./год.; для перехрестя вулиць Липинського - Промислова - Миколайчука від 900 до 1800 од./год. 
Таблиия 1

Залежність тривалості циклів СФР від інтенсивності ТП розрахованої по формулах Ф. Вебстера і А. Міллера

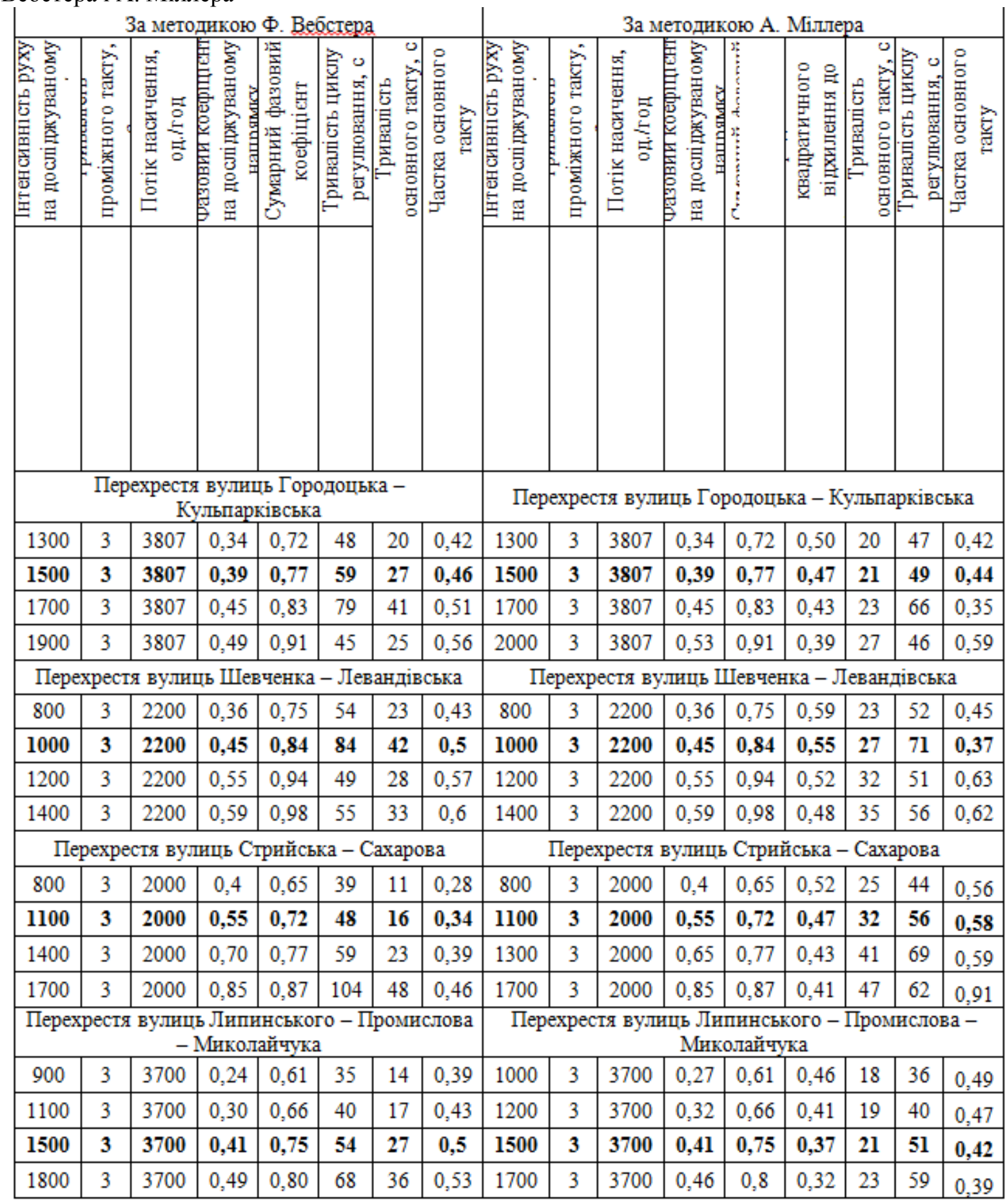

Примітка: виділеним позначено існуючі умови руху (інтенсивність ТП та значення потоку насичення).

3 метою визначення оптимальної тривалості СФЦ за різними методиками проведено моделювання руху ТП у спеціалізованому програмному середовищі PTV VISSIM. Моделювання проводиться за таким алгоритмом: завантажується та калібрується фрагмент супутникової карти 3 досліджуваними перехрестями; будуються вулиці, що підходять до перехрестя, які між собою сполучаються з'єднувальними відрізками згідно дозволених напрямів руху; за результатами натурних досліджень формуються вхідні ТП з відповідним складом, інтенсивністю та максимальною швидкістю руху, а також їх розподіл за напрямками; задаються пріоритети в місцях конфліктів ТЗ; створюються світлофорні об'єкти з відповідними тривалостями фаз та циклів; розташовуються лічильники вимірювання затримок, довжин черг і проставляються маршрути для визначення 
тривалості руху.

Після впровадження усіх заходів, що зазначені у алгоритмі моделювання, побудовано графічні інтерпретації зміни максимальної довжини черги ТЗ, кількості ТЗ, які зупинилися на заборонний сигнал світлофора та тривалості транспортної затримки (рис. 5 - 7).

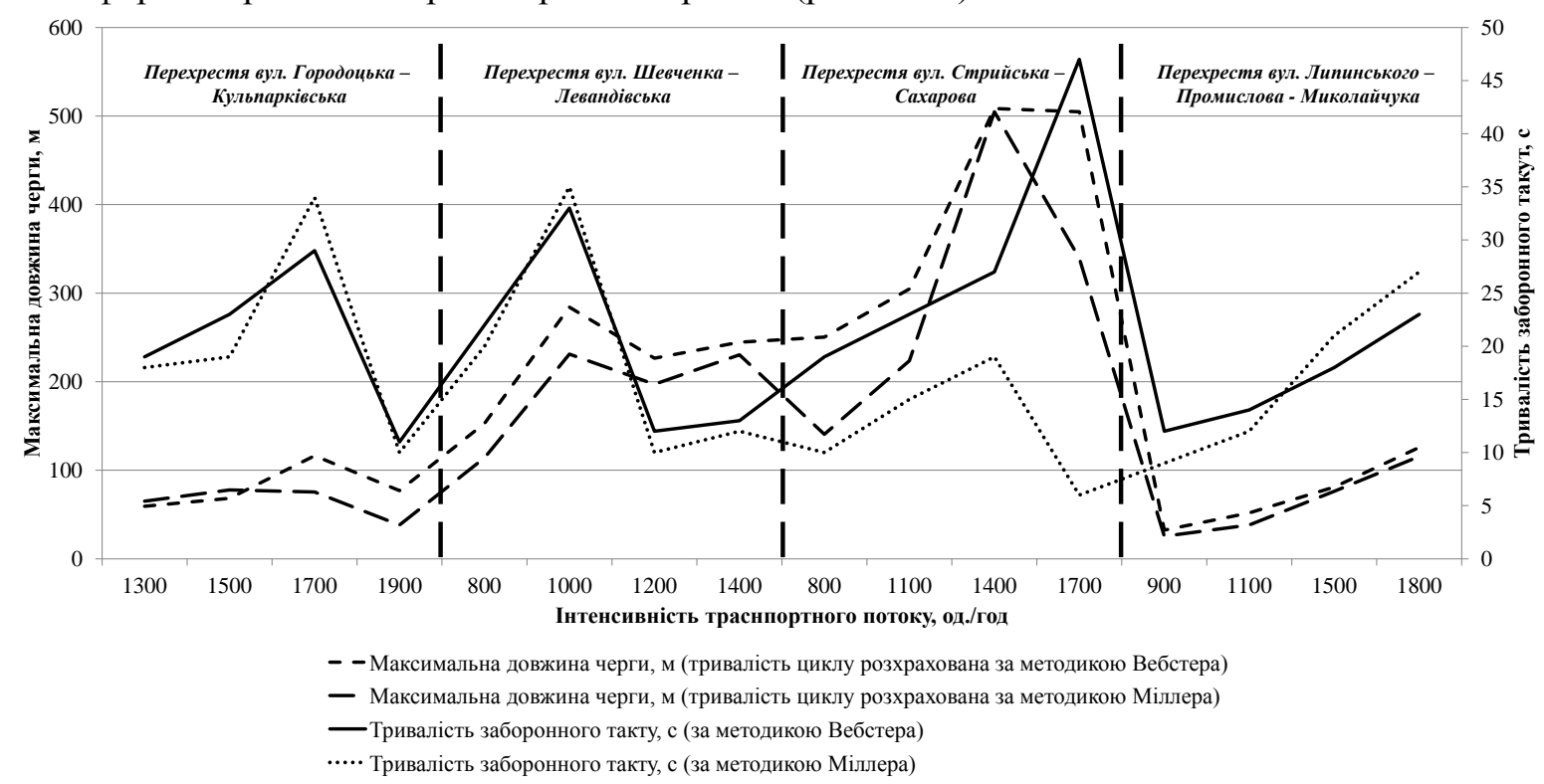

Рисунок 5. Зміна максимальної довжини черги за різних режимів регулювання при збільшення інтенсивності ТП на досліджуваній ділянці

Проаналізувавши рис. 5, можна зробити висновок, що максимальна довжина черги зі збільшенням інтенсивності ТП зростає, проте спостерігається зниження черги ТЗ, для режиму регулювання, який розрахований за методикою А. Міллера. Найменше пониження максимальної довжини черги (за методикою А. Міллера), спостерігається на перехресті вул. Стрийська - Сахарова за інтенсивності ТП 800 од./год і становить 140,55 м.

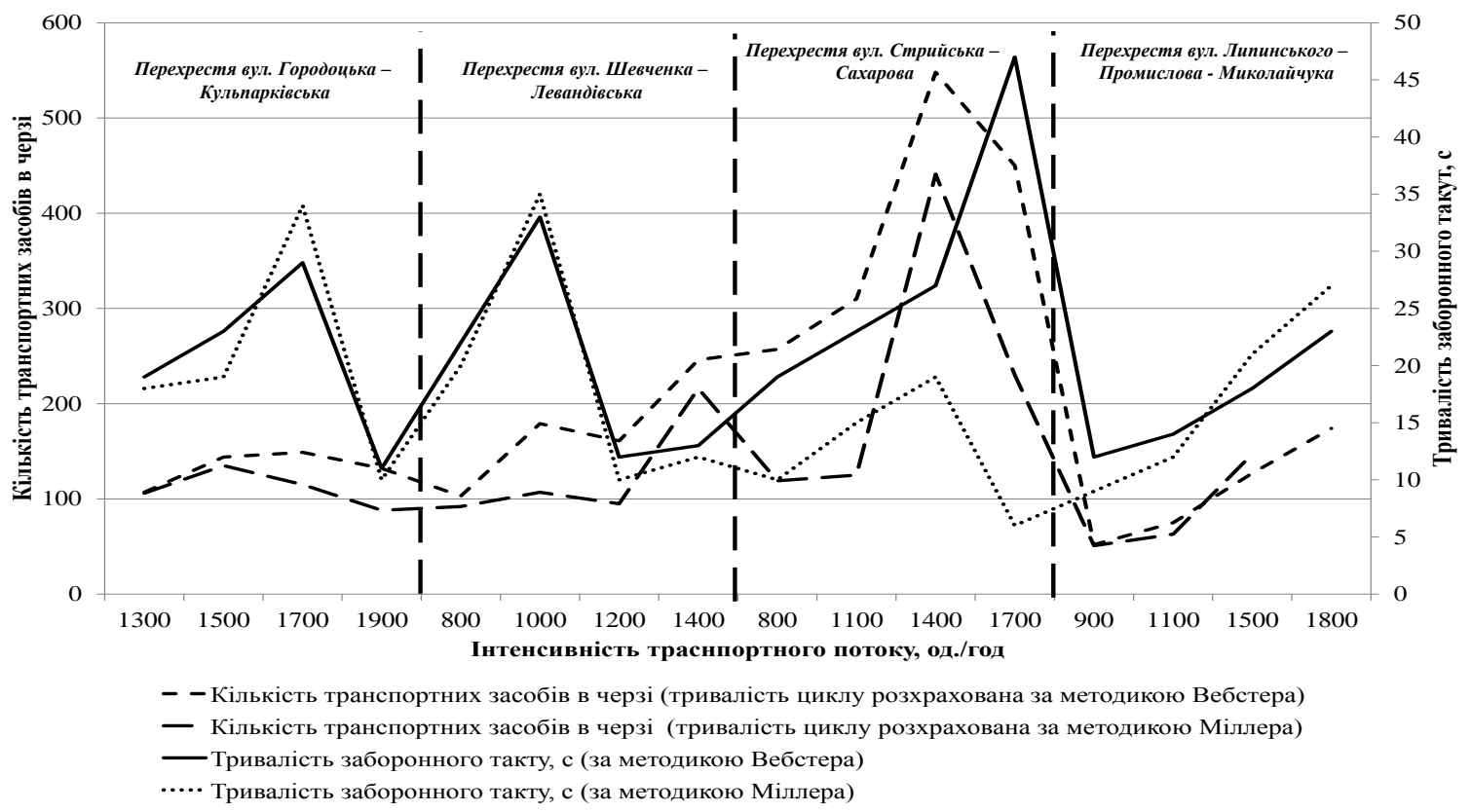

Рисунок 6. Зміна кількості Т3 за різних режимів регулювання при збільшення інтенсивності ТП на досліджуваній ділянці

Згідно рис. 6 можна стверджувати, що за методикою А. Міллера, яка базується на визначені тривалості циклу регулювання, зменшується кількість ТЗ, які зупинилися на заборонний сигнал світлофора у порівнянні із методикою Ф. Вебстера. Варто зазначити, що розбіжність у тривалості циклу регулювання проведеними за двома методиками становить до $10 \%$, змінюється тривалість основного такту на завантажених напрямках. 


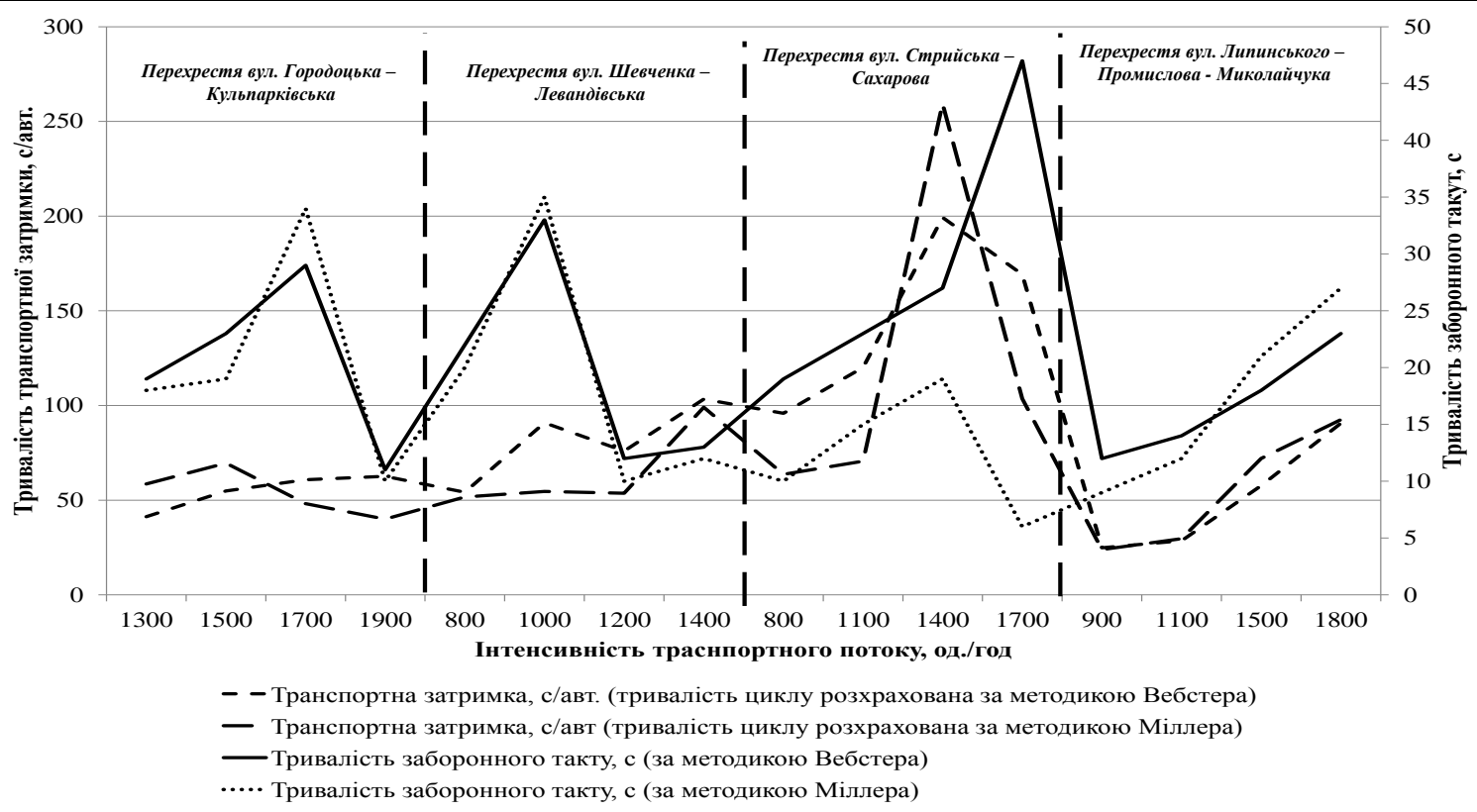

Рисунок 7. Зміна тривалості транспортної затримки за різних режимів регулювання при збільшення інтенсивності ТП на досліджуваній ділянці

Порівнюючи зміну тривалості транспортної затримки за різних режимів регулювання при збільшення інтенсивності ТП на досліджуваній ділянці (рис. 7) встановлено, що за методикою А. Міллера під час визначення тривалості СФЦ регулювання транспортна затримка за існуючих умов руху на перехрестях вулиць Городоцька - Кульпарківська, вулиць Шевченка - Левандівська, вулиць Стрийська - Сахарова, вулиць Липинського - Промислова - Миколайчука становить відповідно 69 с/авт., 54 с/авт., 70 с/авт. та 57 с/авт. Якщо порівнювати значення транспортної затримки при даних умовах руху, за методикою Ф. Вебстера під час визначення тривалості СФЦ регулювання транспортна затримка становить відповідно 63 с/авт., 80 с/авт., 120 с/авт. та 72 с/авт. Отже, можна стверджувати, що тривалість циклу регулювання, яка розрахована за методикою А. Міллера, зменшить затримки на перехрестях в середньому на $20-25 \%$.

Висновки. За результатами цих досліджень, а також досліджень, які проводились нами раніше, можна стверджувати, що найменшого значення довжина черги та тривалість затримки набувають при тривалості циклу, яка розрахована за методикою А. Міллера. Це пояснюється тим що дана методика враховує середнього квадратичне відхилення кількості автомобілів, які прибувають до перехрестя за цикл регулювання та загальну кількість автомобілів, які прибувають до перехрестя.

1.Врубель Ю. А. Определение потерь в дорожном движении: монография / Ю. А. Врубель, Д. В. Капский, Е. Н. Кот. - Минск: БНТУ, 2006. - 240 с.

2. Живоглядов В.Г. Теория движения транспортных и пешеходных потоков: монография / В. Г. Живоглядов. Ростов н / Д.: Изд-во журн. «Изв. Вузов Сев.-Кавк. регион», 2005. - 1082 с.

3. Левашев А. Г. Проектирование регулируемых пересечений: учеб. пособие / А. Г. Левашев, А. Ю. Михайлов, И. М. Головных. - Иркутск: Изд-во ИрГТУ, 2007. - 216 с.

4. Лобанов Е.М. Пропускная способность автомобильных дорог. - М.: Транспорт, 1978. -247 с

5. Організація та регулювання дорожнього руху: підручник / За заг. ред. В. П. Поліщука; О. О. Бакуліч, О. П. Дзюба, В. І. Єресов та ін. - К. : Знання України, 2012. - 467 с.

6. Васильєва Г. Ю. Методи мінімізації затримок транспорту на магістральній вулично-дорожній мережі міст України : автореф. дис. на здобуття наук. ступеня канд. техн. наук : спец. 05.23.20 «Містобудування та територіальне планування»/ Г. Ю. Васильєва. - К., 2007. - 21 с.

7. Webster F. V. Traffic signal Settings and Expected Delay. International Study Week in Traffic Engineering, Stresa, Italy 1956. - p. 315 .

8. Міллер Т.М., Смит У.С., Хард Ф.В. Организация движения (сокращённый перевод с англ.). -М.: Автотранзисдат, 1960.- $464 \mathrm{c}$

\section{REFERENCES}

1. Vrubel', Ju (2006). Determination of losses in road traffic [Opredelenye poter v dorozhnom dvyzhenyy]. Minsk: BNTU, $240 \mathrm{p}$.

2. Zhyvohliadov V. (2005). Theory of traffic and pedestrian flows [Teoriya dvizheniya transportnyih i peshehodnyih potokov]. Rostov-na-Donu, Transport. $1082 \mathrm{p}$.

3. Levashev A. (2007). Design of controlled intersections [Proektirovanie reguliruemyih peresecheniy]. Irkutsk: IrGTU, 216 p. 
4. Lobanov, E. (1978). Road capacity [Propusknaya sposobnost avtomobilnyih dorog]. Moscow, Transport. 247 p.

5. Polishchuk, V. (2012). Traffic organization and management [Orhanizatsiia ta rehuliuvannia dorozhnoho rukhu]. Kyiv, Znannia Ukrainy, $467 \mathrm{p}$.

6. Vasileva G. (2007). The methods of minimization of transport delays on highway cities of Ukraine [Metody minimizatsii zatrymok transportu na mahistralnii vulychno-dorozhnii merezhi mist Ukrainy]. Kyiv: KNUBIA, 21 p.

7. Webster F. V. (1956). Traffic signal Settings and Expected Delay. International Study Week in Traffic Engineering, Stresa, Italy, $315 \mathrm{p}$.

8. Miller T. (1960). Movement organization [Organizatsiya dvizheniya]. Moscow: Avtotranzisdat, 464 p.

Грицунь О.М., Рогальский Р.Б., Бура Р.Р. Определение оптимальной продолжительности светофорного цикла на перекрестках с жесткими типами регулирования.

В работе проведен анализ существующих методов расчета продолжительности светофорного цикла регулирования. Приведено сравнение максимальной длины очереди транспортных средств, количества остановленных автомобилей на запрещающий сигнал светофора и транспортной задержки при различных режимов регулирования (продолжительность цикла рассчитанная по методике Ф. Вебстера и по методике А. Миллера). Установлено, что малейшая задержка наблюдается при продолжительности цикла, которая является рассчитанной по методике А. Миллера.

Ключевые слова: транспортный поток, светофорный цикл, имитационное моделирование, длина очереди, транспортная задержка, интенсивность движения.

O. Hrytsun., R. Rogalskyi, R. Bura. Determination of traffic light cycle optimal duration on intersections with fixedtime control types.

Analysis of existing methods of calculation the traffic light cycle duration is carried out in the work. Comparison of maximum vehicle queue length, number of stopped vehicles on restrictive signal of traffic light and traffic delay upon different control regimes (traffic cycle duration is calculated by the method of F. Webster and the method of A. Miller) is given. It is stated that the least delay is observed upon cycle duration which is calculated by the method of A. Miller.

Keywords: traffic flow, traffic light cycle, simulation modeling, queue length, traffic delay, traffic intensity.

АВТОРИ:

ГРИЦУНЬ Олег Михайлович, асистент кафедри «Транспортні технології», Національний університету «Львівська політехніка», e-mail: oleggrutsyn1993@gmail.com

РОГАЛЬСЬКИЙ Роман Богнадович, кандидат технічних наук, старший викладач кафедри «Транспортні технології», Національний університет «Львівська політехніка», e-mail: roboro@ukr.net

БУРА Романа Романівна, аспірант кафедри «Транспортні технології», Національний університет «Львівська політехніка», e-mail: romana_bura@ukr.net

АВТОРЫ:

ГРИЦУНЬ Олег Михайлович, асистент кафедры транспортных технологий, Национальный университет «Львивська политэхника», e-mail: oleggrutsyn1993@gmail.com

РОГАЛЬСКИЙ Роман Богданович, кандидат технических наук, старший преподаватель кафедры транспортных технологий, Национальный университет «Львивська политэхника», еmail: roboro@ukr.net

БУРА Романа Романовна, аспирант кафедры «Транспортные технологии», Национальний университет «Львовская политехника», e-mail: romana bura@ukr.net

\section{AUTHORS:}

Oleg HRYTSUN, assistant Transport technologies Department, Lviv Polytechnic National University, e-mail: oleggrutsyn1993@gmail.com

Roman ROGALSKYI, PhD in Engineering, Senior Lecturer of Transport Technologies Department, Lviv Politechnic National University, e-mail: roboro@ukr.net

Romana BURA, Postgraduate Student of Transport Technologies Department, Lviv Politechnic National University, e-mail: romana_bura@ukr.net 